\title{
ANALISIS PERWILAYAHAN KOMODITAS KOPI ROBUSTA DI KABUPATEN CIAMIS
}

\section{COMMODITY AREA ANALYSIS OF ROBUSTA COFFE IN CIAMIS REGENCY}

\author{
Saepul Aziz*, Agus Yuniawan Isyanto, Sudrajat, Muhamad Nurdin Yusuf, \\ Anisa Puspitasari
}

\author{
Universitas Galuh, J1. RE Martadinata No. 150 Ciamis 46274
}

*E-mail: alaziz9933@gmail.com

(Diterima 7-1-2021; Disetujui 18-1-2021)

\begin{abstract}
ABSTRAK
Pemetaan potensi wilayah komoditas kopi robusta di kabupaten Ciamis dilakukan sebagai salah satu upaya pengembangan komoditas unggulan sektor perkebunan. Penelitian ini bertujuan untuk mengidentifikasi wilayah basis produksi kopi robusta dan karakteristik penyebarannya di kabupaten Ciamis. Data yang digunakan adalah data sekunder berupa data time series mulai dari tahun 2017-2019. Analisis yang digunakan adalah analisis Location Quotient (LQ), analisis Lokalita dan analisis Spesialisasi. Berdasarkan hasil penghitungan dengan menggunakan indikator produksi kopi robusta dapat dikatahui bahwa wilayah basis komoditas kopi robusta di kabupaten Ciamis terdapat pada 13 wilayah dari 26 kecamatan. Kegiatan usahatani kopi robusta tidak terlokalisasi pada suatu wilayah melainkan menyebar di beberapa kecamatan, dan tidak menspesialisasikan pada usahatani kopi robusta.
\end{abstract}

Kata Kunci : Kopi Robusta, LQ

\section{ABSTRACT}

The mapping of the potential areas for Robusta coffee in Ciamis regency is done as an effort to develop superior commodities in the plantation sector. This study aims to identify the area of Robusta coffee production base and its distribution characteristics in Ciamis regency. The data used is secondary data in the form of time series data starting from 2017-2019. The analysis used is the Location Quotient (LQ) analysis, locality analysis and specialization analysis. Based on the results of calculations using the robusta coffee production indicator, it can be seen that the base area for the Robusta coffee commodity in Ciamis district is in 13 out of 26 sub-districts. Robusta coffee farming activities are not localized in an area but spread across several districts and do not specialize in robusta coffee farming.

Keyword: robusta coffee, $L Q$

\section{PENDAHULUAN}

Kopi merupakan salah satu komoditas perkebunan yang memegang peranan cukup penting dalam perekonomian Indonesia. Kontribusi penting dari komoditas kopi bagi perekonomian nasional tercermin pada kinerja perdagangan dan peningkatan nilai tambahnya. (Direktorat Jendral Perkebunan, 2020). Kopi juga berperan sebagai penyedia lapangan kerja dan sumber pendapatan bagi masyarakat (Thamrin, 2016 dalam Bangun, 2020). 
Produksi kopi Indonesia mengalami fluktuasi dari tahun ke tahun. Hampir semua propinsi di Indonesia mampu menghasilkan kopi, kecuali DKI Jakarta. Lahan kopi terluas erletak di Propinsi Sumatera Selatan yaitu sebsar 277.542 ha dengan produksi sebesar 140.812 ton. Produksi kopi tertinggi dihasilkan oleh provinsi Lampung sebesar 142.599 ton dengan luas lahan sebesar 166.058 Ha. Sebaran produksi kopi di Indonesia tidak merata di seluruh daerah/ provinsi sehingga hal ini akan menyebabkan wilayah-wilayah basis komoditas kopi di Indonesia hanya terpusat pada satu daerah/ provinsi saja. Salah satu aspek yang harus diperhatikan dalam upaya pengembangan komoditas kopi adalah memperhatikan kondisi dari masing-masing wilayah,.(Kusmiati A, 2011) Komoditas unggulan memiliki posisi strategis untuk dikembangkan di suatu wilayah yang penetapannya didasarkan pada berbagai pertimbangan.(Sihombing, 2018 dalam Isyanto dkk, 2019).

Kabupaten Ciamis merupakan salah satu wilaya yang potensial untuk budidaya kopi robusta. Produksi kopi robusta pada tahun 2019 mencapai 963,95 ton dengan luas area $2.797,27$ hektar (BPS Jabar, 2019). Budidaya kopi robusta di Kabupaten Ciamis sebagian petani ikut tergabung dalam Lembaga Masyarakat Desa Hutan (LMDH) sehingga memudahkan petani kopi untuk mendapatkan pendampingan baik dalam budidaya mapun penangan pasca panen.

Salah satu faktor dalam upaya pengembangan suatu komoditas pertanian adalah potensi wilayah, sehingga perencanaan wilayah yang menjadi komoditas unggulan perlu diperhatikan. Kusmiati \& Windiarti (2011) dalam Bangun (2020) juga berpendapat bahwa perencanaan wilayah dalam pengembangan komoditas pertanian merupakan hal yang sangat penting karena setiap wilayah memiliki nilai strategis sesuai dengan potensi sumber daya yang terdapat pada masing-masing daerah.

Penelitian mengenai pemetaan potensi wilayah sudah dilakukan oleh Bangun (2020) tentang analisis perwilayahan komoditas dan kontribusi kopi Arabika terhadap pembangunan wilayah di Kabupaten Tapanuli Utara. Susanto et al (2017) melakukan penelitian tentang perwilahan dan strategi pengembangan peternakan kambing di Kabupaten Lumajang.

Berdasarkan uraian di atas, perlu adanya suatu kajian tentang pemetaan 
potensi wilayah komoditas kopi robusta di kabupaten Ciamis. Penelitian ini bertujuan untuk mengidentifikasi wilayah basis produksi kopi robustaa dan karakteristik penyebarannya.

\section{METODE PENELITIAN}

Data yang digunakan dalam penelitian ini adalah data sekunder yang diambil dari publikasi Badan Pusan Statistik (BPS) Kabupaten Ciamis. Data yang dikumpulkan berupa data time series selama tiga tahun mulai dari 2017 sampai 2019. Variabel yang digunakan yaitu produksi kopi dan komoditas perkebunan lainnya yang diusahakan oleh masyarakat di masing-masing wilayah kecamatan di Kabupaten Ciamis.

Metode analisis yang digunakan untuk mengetahui wilayah basis dan non basis komoditas kopi di Kabupaten Ciamis menggunakan metode analisis Location Questiont (LQ) dengan formulasi sebagai berikut (Bangun, 2019; Iswi dan Santoso, 2015):

$$
L Q_{i}=\frac{y_{i j} / y_{j}}{Y_{i} / Y}
$$

Keterangan:

$$
\begin{array}{rll}
\text { LQi } & \text { : } & \text { Location Quotient } \\
\text { Yij } & : & \text { Produksi kopi di kecamatan i } \\
\text { Yi } & : & \text { Produksi komoditas } \\
& & \text { perkebunan di kecamatan i }
\end{array}
$$

$\begin{array}{rlrl}\text { Yi } \quad \text { Produksi kopi di } & \text { Kabupaten } \\ & \text { Ciamis } & & \\ \text { Y } \quad \text { Produksi } & & \text { komoditas } \\ & \text { perkebunan di } & \text { Kabupaten } \\ & \text { Ciamis } & & \end{array}$

Kriteria pengambilan keputusan sebagai berikut:

- Jika nilai LQ > 1 artinya wilayah tersebut merupakan kecamatan basis komoditas kopi. Produksi komoditas kopi di kecamatan tersebut tidak hanya mampu memenuhi kebutuhan untuk wilayahnya, namun dapat diekspor ke luar wilayah.

- Jika nilai $\mathrm{LQ}<1$ artinya wilayah tersebut bukan merupakan kecamatan basis komoditas kopi. Produksinya hanya cukup untuk memenuhi kebutuhan di dalam wilayah kecamatan tersebut.

Metode analisis yang digunakan untuk mengetahui karakteristik penyebaran komoditas kopi di Kabupaten Ciamis adalah analisis lokalita dan spesialisasi. Koefisien lokalita digunakan untuk mengukur penyebaran dari kegiatan pertanian wilayah dengan rumus (Widyatami \& Wiguna, 2017 dalam Bangun, 2019):

$$
\alpha_{i}=\left[S_{i} / N_{i}\right]-\left[\sum S_{i} / \sum N_{i}\right]
$$


Keterangan:

$\alpha \quad$ : koefisien lokalisasi komoditi kopi

Si : Produksi komoditas kopi di kecamatan i

Ni : Produksi komoditas kopi di Kabupaten Ciamis

$\sum S_{i}:$ Total produksi komoditas perkebunan di kecamatan $\mathrm{i}$

$\sum N_{i}:$ Total produksi komoditas perkebunan di Kabupaten Ciamis

Kriteria pengambilan keputusan:

- $\alpha \geq 1$ artinya komoditas kopi terlokalisasi atau terkonsentrasi pada suatu wilayah kecamatan

- $\alpha<1$ artinya komoditas kopi tersebar di beberapa kecamatan di kabupaten Ciamis

Koefisien spesialisasi digunakan untuk mengukur tingkat spesialisasi suatu daerah kegiatan tertentu. Formula koefisien spesialisasi sebagai adalah sebagai berikut ( Nurmalia dan Suwandari, 2019 dalam Bangun R.H. 2020)

$$
\beta_{i}=\left[S_{i} / \sum S_{i}\right]-\left[N_{i} / \sum N_{i}\right]
$$

Keterangan :

$$
\begin{aligned}
\beta_{i}: & \text { koefisien } \\
& \text { komoditas kopi }
\end{aligned}
$$

Si : Produksi komoditas kopi di kecamatan i

Ni : Produksi komoditas kopi di Kabupaten Ciamis

$\sum S_{i}$ : Total produksi komoditas perkebunan di kecamatan i

$\sum N_{i}$ : Total produksi komoditas perkebunan di Kabupaten Ciamis

Kriteria pengambilan keputusan:

- $\beta \geq 1$ artinya wilayah kecamatan sudah menspesialisasikan pada usaha komoditas kopi

- $\beta<1$ artinya wilayah kecamatan belum menspesialisasikan pada usaha komoditas kopi

\section{HASIL DAN PEMBAHASAN}

Perkembangan Produksi Kopi Robusta

Produksi kopi robusta di Kabupaten Ciamis pada tahun 2019 mengalami kenaikan sebesar 4,95 persen dari ratarata produksi kopi pada tahun 2018 sebesar 4,07 persen (BPS Kabupaten Ciamis, 2020). Peningkatan produksi kopi robusta di Kabupaten Ciamis mengindikasikan tingginya minat masyarakat untuk melakukan usaha budidaya kopi robusta. Kondisi ini juga turut mendukung pengembangan kopi 
robusta di kabupaten Ciamis sebagai salah komoditas unggulan.

\section{Wilayah Basis Komoditas Kopi \\ Robusta}

Perwilayahan komoditas unggulan merupakan komoditas unggulan yang akan dikembangkan oleh masing-masing wilayah kecamatan. Penentuan basis dan non basis dapat diketahui berdasarkan nilai LQ dari komoditas kopi robusta untuk masing-masing kecamatan. Nilai rata-rata LQ kopi robusta berdasarkan indikator produksi kopi robusta di Kabupaten Ciamis tahun 2017-2019 dapat dilihat pada Tabel 1 .

Tabel 1. Rata-rata LQ Komoditas Kopi Robusta di Kabupaten Ciamis

\begin{tabular}{rlc}
\hline No & Kecamatan & Nilai Rata-rata LQ \\
\hline 1 & Banjarsari & 0,53 \\
2 & Baregbeg & 0,19 \\
3 & Ciamis & 0,44 \\
4 & Cidolog & 2,95 \\
5 & Cihaurbeti & 0,65 \\
6 & Cijengjing & 1,15 \\
7 & Cikoneng & 0,60 \\
8 & Cimaragas & 2,40 \\
9 & Cipaku & 0,54 \\
10 & Cisaga & 3,40 \\
11 & Jatinagara & 0,54 \\
12 & Kawali & 0,22 \\
13 & Lakbok & 0,07 \\
14 & Lumbung & 0,49 \\
15 & Pamarican & 2,02 \\
16 & Panawangan & 3,65 \\
17 & Panjalu & 3,05 \\
18 & Panumbagan & 2,12 \\
19 & Purwadadi & 0,04 \\
20 & Raja Desa & 1,22 \\
21 & Rancah & 1,66 \\
22 & Sadananya & 0,15 \\
23 & Sindangkasih & 0,19 \\
24 & Sukadana & 2,30 \\
25 & Sukamantri & 1,94 \\
26 & Tambaksari & 2,89 \\
\hline Sumber: BPS Kabupaten Ciamis, 2019 \\
\hline
\end{tabular}

Tabel 1 menunjukkan bahwa kopi robusta menjadi salah satu komoditas yang banyak diusahakan oleh masyarakat setempat pada wilayah kecamatan basis tersebut. Terdapat 13 kecamatan dari 26 kecamatan di Kabupaten Ciamis yang menjadi wilayah unggulan untuk dapat dikembangkan dalam rangka meningkatkan perekonomian daerah dan kesejahteraan masyarakat. Salah satu faktor pendukung yang mempengaruhi suatu wilayah menjadi wilayah basis produksi komoditas kopi adalah kesesuaian kondisi tanah, iklim, cuaca, teknik budidaya yang tepat serta penggunaan teknologi yang tepat guna dalam budidaya kopi (Kusmiati dan Windiarti, 2011).

\section{Karakteristik penyebaran komoditas kopi robusta di kabupaten Ciamis}

Karakteristik penyebaran kopi robusta di Kabupaten Ciamis dapat diketahui dari hasil penghitungan analisis lokalita dan analisis spesialisasi. Analisis lokalita digunakan untuk mengetahui apakah komoditas kopi robusta terkonsentrasi pada suatu wilayah atau menyebar di beberapa wilayah. Sedangkan analisis spesialiasi sebagai gambaran masing-masing wilayah kecamatan apakah menspesialisasikan 
satu komoditas kopi saja atau tidak. Untuk lebih jelasnya disajikan pada tabel 2.

Tabel 2. Hasil Penghitungan Lokalisasi dan Spesialiasi Komoditas Kopi Robusta di Kabupaten Ciamis

\begin{tabular}{|c|c|c|c|}
\hline No & Kecamatan & $\begin{array}{c}\text { Koefisien } \\
\text { Lokalita }(\alpha)\end{array}$ & $\begin{array}{c}\text { Koefisien } \\
\text { Spesialisasi } \\
(\beta)\end{array}$ \\
\hline 1 & Banjarsari & -0.06 & -0.04 \\
\hline 2 & Baregbeg & -0.04 & -0.07 \\
\hline 3 & Ciamis & -0.01 & -0.05 \\
\hline 4 & Cidolog & 0.01 & 0.16 \\
\hline 5 & Cihaurbeuti & -0.01 & -0.03 \\
\hline 6 & Cijeungjing & 0.00 & 0.01 \\
\hline 7 & Cikoneng & -0.01 & -0.03 \\
\hline 8 & Cimaragas & 0.01 & 0.12 \\
\hline 9 & Cipaku & -0.04 & -0.04 \\
\hline 10 & Cisaga & 0.02 & 0.20 \\
\hline 11 & Jatinagara & -0.02 & -0.04 \\
\hline 12 & Kawali & -0.06 & -0.06 \\
\hline 13 & Lakbok & -0.08 & -0.08 \\
\hline 14 & Lumbung & -0.02 & -0.04 \\
\hline 15 & Pamarican & 0.01 & 0.08 \\
\hline 16 & Panawangan & 0.18 & 0.22 \\
\hline 17 & Panjalu & 0.02 & 0.17 \\
\hline 18 & Panumbangan & 0.01 & 0.09 \\
\hline 19 & Purwadadi & -0.09 & -0.08 \\
\hline 20 & Rajadesa & 0.01 & 0.02 \\
\hline 21 & Rancah & 0.01 & 0.05 \\
\hline 22 & Sadananya & -0.06 & -0.07 \\
\hline 23 & Sindangkasih & -0.03 & -0.07 \\
\hline 24 & Sukadana & 0.02 & 0.11 \\
\hline 25 & Sukamantri & 0.01 & 0.08 \\
\hline 26 & Tambaksari & 0.02 & 0.16 \\
\hline
\end{tabular}

Hasil penghitungan menunjukkan bahwa koefisien lokalita yang dihasilkan dari masing-masing kecamatan besarnya kurang dari $1 \quad(\alpha<1)$. Artinya usaha perkebunan kopi robusta di Kabupaten Ciamis tidak terkonsentrasi pada satu wilayah kecamatan, tetapi tersebar di beberapa kecamatan. Nurmalia \& Suwandari (2019) dalam penelitiannya menyimpulkan bahwa penyebaran kegiatan usaha pertanian dapat memberikan keuntungan bagi pelaku usaha yang berkaitan karena jika kebutuhan terhadap komoditas pertanian tidak diperoleh di satu kecamatan maka masih ada kecamatan lain yang dijadikan rujukan untuk memenuhi kebutuhan akan komoditas pertanian tersebut. Selain itu Churfa et al (2015) juga menyebutkan bahwa penyebaran komoditas pertanian akan memberikan dampak positif bagi pemenuhan komoditas pertanian.

Sedangkan untuk analisis spesialiasi menunjukkan bahwa tidak terdapat wilayah kecamatan yang memiliki nilai indeks spesialiasi lebih dari satu $(\beta>1)$. Artinya, tidak ada wilayah kecamatan yang menspesialisasikan komoditas kopi robusta. Pasaribu dan Soetriono (2009) dalam Bangun (2020) menjelaskan bahwa tidak adanya wilayah yang menspesialisasikan wilayahnya pada pngusahaan komoditas tertentu mengindikasikan bahwa terdapat keragaman komoditas yang diusahakan oleh masyarakat untuk pemenuhan kebutuhan di wilayah tersebut.

Berdasarkan Tabel 2 dapat diketahui bahwa terdapat 13 dari 26 kecamatan yang mempunyai nilai koefisien spesialisasi positif yaitu Kecamatan Cijeungjing, Cidolog, Cimaragas, Cisaga, Pamarican, 
Panawangan, Panjalu, Panumbangan, Rajadesa, Rancah, Sukadana, Sukamantri, dan Tambaksari. Kecamatan tersebut merupakan kecamatan basis komoditas kopi robusta di kabupaten Ciamis. Hal ini sejalan dengan penelitian Bangun (2020) pada komoditas kopi arabika memperlihatkan bahwa adanya spesialisasi komoditas kopi arabika hanya terdapat pada wilayah basis karena wilayah basis lebih tinggi produksinya. Begitu juga dengan penelitian Chufa et al (2015) yang menyatakan bahwa spesialisasi kopi dapat diketahui dari wilayah basis.

\section{KESIMPULAN DAN SARAN}

\section{Kesimpulan}

Wilayah basis komoditas kopi robusta di kabupaten Ciamis terdapat pada 13 kecamatan, yaitu Cijeungjing, Cidolog, Cimaragas, Cisaga, Pamarican, Panawangan, Panjalu, Panumbangan, Rajadesa, Rancah, Sukadana, Sukamantri, dan Tambaksari. Karakteristik penyebaran usaha perkebunan kopi robusta di Kabupaten Ciamis tidak terkonsentrasi pada satu wilayah kecamatan, tetapi tersebar di beberapa kecamatan, dan tidak ada wilayah kecamatan yang menspesialisasikan komoditas kopi robusta.

\section{Saran}

Wilayah basis diharapkan mampu memenuhi kebutuhan kopi robusta wilayah non basis dengan peningkatan produksi kopi dengan lebih mengintensifkan dalam kegiatan usatani kopi robusta serta memeperluas jaringan pemasaran biji berasan kopi mapun melakukan pengolahan pasca panen untuk meningkatkan nilai tambah. Sedangkan untuk wilayah non basis LQ $<1$ dapat meningkatkan produksi kopi robusta dengan cara intensifikasi dan perluasan area tanam kopi robusta. Upaya peningkatan porduksi tidak terlepas dari peranan pemerintah kepada petani dalam bentuk akses infromasi, dan kemudahan sarana prasarana produksi.

\section{DAFTAR PUSTAKA}

Bangun RH. 2020. Analisis Perwilayah Komoditas dan Kontribusi Kopi Arabika Terhadap Pembangunan Wilayah Kabupaten Tapanili Utara. Junal Agriuma. 2(1); 1-10

BPS Kabupaten Ciamis 2019. Kabupaten Ciamis dalam Angka. Ciamis.

BPS Provinsi Jawa barat. 2019. Provinsi Jawabarat Dalam Angka. Bandung. BPS Prov. Jawa Barat.

Churfa, D., Sholihah, H., Murti, J., Aji, M., \& Kuntadi, E. B. (2015). Analisis Perwilayahn Komoditas Dan Kontribusi Subsektor 
Perkebunan Kopi Rakyat Di Kabupaten Jember. Berkala Ilmiah Pertanian, 1(2), 1-9.

Direktorat Jendral perkebunan. 2020. Statistik Perkebunan Indonesia, Jakarta. Sekretariat Direktorat Jenderal Perkebunan.

Iswi, A., \& Santoso, B. (2015). Perwilayahan Komoditas Unggulan Tanaman Pangan Berdasarkan Kesesuaian Lahan Kabupaten Tuban. Jurnal Teknik ITS, 4(1), 27.

Isyanto A.Y. Sudrajat, Yusuf, M.N. Novianty, A. Andrie B.M. Priantika W. Harli, N. Aziz, S. 2019. Komoditas Potensial Tanaman
Palawija Di Kabupaten Blora Provinsi Jawa Tengah. Mimbar Agribisnis. 5(2);368-378.

Kusmiati A dan Reni Windiarti. 2011. Analisis Wilayah Komoditas Kopi di Indonesia. J-SEP 5(2): 47-58

Nurmalia, R., \& Suwandari, A. (2019). Analisis Perwilayahan Dan Kontribusi Komoditas Jeruk Siam Terhadap Perekonomian Kabupaten Banyuwangi. SEPA, 16(1), 85-96.

Susanto, A. D., Soetriono, S., \& Supriono, A. (2017). Analisis Perwilayahan dan Strategi Pengembangan Peternakan Kambing di Kabupaten Lumajang. Sorot, 12(2), 107-120. 